\title{
The Social Power of Literature: How Could a Novel Resist to What is Wrong with a Culture?
}

\author{
Mario Francisco Benvenuto ${ }^{1}$, Rossella Michienzi ${ }^{2, *}$ \\ ${ }^{1}$ University of Calabria (Italy), resident in Montalto Uffugo (Cs) 87040 \\ ${ }^{2}$ University of Calabria (Italy), resident in Maierato (VV) 89843 \\ *Corresponding Author: michienzirossella@gmail.com
}

Copyright $@ 2013$ Horizon Research Publishing All rights reserved.

\begin{abstract}
This paper represents an attempt to describe the society of "norms" and ideals which lead to the destruction of the body. The Edible Woman by Margaret Atwood lends itself well to an exploration of this complex condition. This is particularly true if we consider the fact that Margaret Atwood writes about the female body in terms of the culture that determines it. Atwood's female bodies tell the story of the subjects' experience within a system that seeks to consume them. Susan Bordo finds Foucault's model of self-surveillance useful for the analysis of femininity is reproduced through a process of self-normalization to cultural ideals of the perfect face or the perfect body. According to Susan Bordo anorexia must be defined within a cultural context. Bordo feels that it is through eating disorders that resistance to the dominant ideological system is made known. But at the same time this resistance also destroys the contemporary female body. In conclusion we could claim that body image is strongly influenced by social norms about physical beauty. We will see how the human body is introduced in a mechanism of power with a social basis, that explores it, breaks it down and rearranges it.
\end{abstract}

Keywords Social Power, Anorexia Nervosa, Dominant Ideological System

\section{Introduction}

"Il nostro mondo senza letteratura sarebbe impoverito non solo di emozioni - come comunemente si crede - ma anche di conoscenza. Di conoscenza di noi stessi e della realtà. La letteratura riattiva le zone d'ombra e, per il fatto steso di essere finzione, fa affiorare dubbi e domande, mette in discussione il senso comune. Svelando mondi paralleli, proprio perché è finzione svela la non necessità di ciò che è successo, e serve - come dice Javier Marías (1994) - come promemoria di quelle parti, di quelle dimensioni che siamo soliti tralasciare soprattutto quando cerchiamo di spiegare, di definire".

Using Gabriella Turnaturi's words (Andare Oltre, 2013, p.
204): literature is one of the most important tools with which is reactivate areas kept in shadow and as the writer George Eliot argues: the art of novel is a way to enrich the experience beyond the boundaries of our personal destiny 1 . The idea of perceiving literary works as a cognitive instrument, rises in an extraliterary field and it is a consequence of anthropological, sociological and psychopedagogical studies dating back to the end of the XIX century. As the great literary theorist Remo Ceserani has claimed, the discovery of the cognitive value of narration "gives suddenly to literature (whose food are stories), a space of extraordinary importance in our mental, social and cultural life, but also a notable responsibility" (Ceserani, 1999, p. 202). Literature represents an almost inexhaustible source of signs interwoven deeply within the aspects of a given society. Such signs make novelists and scholars, creators of literary images able to create new lights on lives practiced by social sciences (Cfr. Parini, 2012).

As Paolo Jedlowski 2 points out, departing from the assumption that literature creates, at least partly, the reality that it describes, we will see how it is used as the only tool through which it is possible to create a liberation, give life to a resistance with respect to the dominant ideological system to be subverted. This resistance is expressed in the novel we are considering here, through eating disorders. Specifically we will refer to anorexia, that of Marian, the protagonist of The Edible Woman, a pre-feminist novel written by Margaret Atwood.

We will try to understand the paradox that the novel proposes: that of a contemporary female body that is relentlessly destroyed by the resistance / rebellion which should preserve it.

\section{The Rejection of the "Norm" in a Novel by Margaret Atwood}

1 Wood, J. (2008), Come funzionano i romanzi, It.tr., Mondadori, Milano, 2010, p.109.

2 Cfr. Jedlowski, P., Storie comuni. La narrazione nella vita quotidiana, Mondadori, Milano, 2000. 
The most important thing to be understood is that we live in a world of norms and while many of us endeavor to be normal others try to avoid that state of "normalcy". In the following work we will find useful to define the concept of "norm". This concept could be metaphorically explained with the gaussian Gauss Curve, that is an innovative mathematical concept whose implications with the real world are very significant: the concept of a norm implies that the majority of a population should be part of the norm. The norm pins down the majority of the population that falls under the arch of the standard bell-shaped curve. So, as a consequence, that curve begins to be considered the symbol of the tyranny of the norm itself3. These concepts are closely related to the famous objective characterizing eugenics whose principle aim is to lead to the improvement of the species. This aim is summarized in Hitler's famous declaration: "the struggle for the daily livelihood [between species] leaves behind, in the ruck, everything that is weak or diseased or weaving" 4 . The search for perfection submits whatever embodies the subverted ideal of frailty and imperfection.

As Susan Bordo claims in many of her essays and as Jules Henry also states, psychopathology is the final outcome of all that is wrong with a culture and, we could add, with a society. Specifically, eating disorders such as bulimia or anorexia are multidimensional disorders and anorexia, in particular, is related to a key concept elaborated by Kim Chernin5 and defined as "the tyranny of slenderness". The point is the following: why are we so obsessed with keeping our body slim? Women, and those people who want to embody the "norm", consciously or unconsciously turn their body into a locus of social control.

The Edible Woman by Margaret Atwood is a novel whose protagonist, Marian, tries to fight against a tainted social system. Suddenly and unconsciously, Marian develops a strange illness: she rejects food. According to her mother it was due to a state of excitement and she thinks that eating living beings is not ethical so, at first, she rejects meat, eggs (the yellow yolk seems to be a great eye staring at her) and then vegetables. Her friend Duncan explains this inexplicable madness to her. Marian was probably not just rejecting food but also the social system. On the surface, everything is well and normal: Marian is a clever, educated, young woman... She leads a "normal" life. It is not by chance that Marian works within a great company known as "Seymour", where studies about public opinion are conducted:

\section{"Sometimes I wonder just which things are part of my job, especially when I find myself calling up garage mechanics to ask them about their pistons [...]. I know what Seymour}

\footnotetext{
3 Cfr. Davis, J. L. (ed.), The Disability Studies Reader, Routledge, New York and London, 1997.

4 Blacker, C. P., Eugenics: Galton and After, Harvard University Press, Cambridge, 1952, p. 143.

5 Cfr. Chernin, K., The Obsession: Reflections on the Tyranny of Slenderness: Harper \& Row, New York, 1981.
}

\begin{abstract}
Surveys hired me as - I'm supposed to spend my time revising the questionnaires, turning the convoluted and overly subtle prose of the psychologists who write them into simple questions which can be understood by the people who ask them as well as the people who answer them." 6
\end{abstract}

Marian's work is to rewrite questionnaires changing the complicated prose of the psychologists and elaborating them into simple questions comprehensible to everyone. The distinction between different classes is clear, as is the inferiority of common people associated to a "grotesque" language. Once again we could identify a sort of state of submission with respect to a dominant system, that system occupied by a strong, sane and possibly "male" human being. From our point of view, what Margaret Atwood is proposing through her novel, is a mirror to the social construction of disability: a woman enabled by the same society who at a certain point decides to undergo a silent protest. As Susan Wendell claims:

"Our real human bodies are exceedingly
diverse - in size, shape, colour, texture,
structure, function, range and habits of
movement and development - and they are
constantly changing. Yet we do not absorb or
reflect this simple fact in our culture. Instead
we idealize the human body. Our physical
ideals change from time to time, but we
always have ideals. These ideals are not just
about appearance, they are also ideals of
strength and energy and proper control of the
body. We are bombarded with images of these
ideals, demand for them [...]. Idealizing the
body prevent everyone, able-bodied and
disabled, from identifying with and loving
her/his real body"7.

Wendell's words refer to the condition of disabled women who struggle with both the oppressions of being women in a male-dominated society and the oppression of being disabled in societies where able-bodied people prevail. Metaphorically speaking, Marian is fighting against a faulty society disabling herself through an eating disorder, the only instrument she could use in order to prevent the manipulation of her body by society.

What Margaret Atwood proposes in her novel is the reflex of the insane social construction of disability8: a woman disabled by the same society who begins a silent protest; refusing food, Marian refuses to be checked upon, and to be subdued, thus begins a struggle against her body, in which she is a poor prisoner. The refusal of food represents the

6 Atwood, M., The Edible Woman, Anchor Books, New York, 1998, p.21. 7 Wendell, S., "Toward a Feminist Theory of Disability", in Davis, J. L. (ed.), The Disability Studies Reader, Routledge, New York and London, 1997 , p. 267.

8 Davis J. L. (a cura), The disability Studies Reader. 
triumph of the mind over the body. In Orbach's words: anorexia becomes a sort of "strike of the hunger" 9 , beginning a political discourse in which the drastic transformation of the body and the refusal of food say what she doesn't succeed in expressing through words. The body becomes a form of communication and Margaret Atwood chooses the metaphor of anorexia as a useful narrative expedient in order to give voice (through Marian's annoyance) to what, unfortunately, continues to be a social paradox. A fundamental key for the comprehension of the novel is its structure. It is made up of three sections: in the first section there is the first person narrator, in the second the story is delineated under the eyes of the reader through a third narrating voice, with the first person coming back in the last part. These various sections correspond respectively to the moment before her engagement, to her actual engagement, and to her return to the status of being single. The third person of the second section perfectly represents a Marian who doesn't have control of herself anymore, a control that is reacquired only at the very end when she renounces her fiancé who would have otherwise ended up devouring her, and when she makes herself, challenging the title, uneatable. She achieves this by making a cake, an accurate reflection of his image and offering it to Peter, a gesture through which she regains her independence. Paradoxically, her cooking for a man, once again reincarnates the social ideal of femininity.

\section{Subverting a System through Literature: The Body from Locus of Control to Place of Rebellion}

The narration becomes the way where the union between body and mind is realised. Legend has it that human existence is bifurcated into two realms or substances: the bodily or material, on the one hand, and the mental or spiritual, on the other hand. Bordo considers three important positions: for Descartes the body is the brute material envelope for the inner and essential self, as mechanical in its operations as a machine, and as a consequence it is comparable to animal existence; for Plato the body is a sort of prison, it is a cage from which the soul, the will, or mind struggle to escape. According to Augustine, the body is the enemy of the mind because it is the source of obscurity and confusion in our mind. From these perspectives which consider the body a tool, the body itself could become the place of social control. Just think about the nineteenth century hourglass figure which, emphasizing breasts and hips, was an intelligible symbolic form, representing a domestic ideal of femininity. The cultural contrast between the female and the male form, made possible by the use of the corset, reflected the dualistic division of social and cultural life into clearly defined female and male spheres. In

9 Orbach, S., Hunger Strike: Anorexia as a metaphor for Our Time, W.W. Norton, New York, 1986. order to achieve the specified look a particular praxis was required - minimal eating, reduced mobility - rendering the female body unfit to perform activities outside of its sphere.

This is, precisely, what Foucault defines the useful body. The temptation, the desire to embody an aesthetical norm, an ideal leading to the creation of docile bodies. A clear example could be found in L'homme-machine by La Mettrie, in which human beings are described as mechanical products of society. La Mettrie introduces the concept of dressage (training of the body) and Foucault departs from this point in the construction of his theory that unites the idea of the observable body to that of the manipulable body. According to Foucault the constant control over the body would prevent that deviation from the norm described before, creating therefore docile bodies. Foucault and Bordo are absolutely aware of one thing: the body is strongly influenced by the social norms related to the necessity of a form that corresponds to the physical ideal of the perfect face and the perfect body.

\section{Conclusion}

As it is clear through this short analysis of Atwood novel, it is precisely the preoccupation to embody the "norm" which leads to the creation of docile bodies (these bodies are sensitive to any departure from social norms and accustomed to self-improvements and self-transformation in the service of those norms).

So, we could claim that body image is strongly influenced by social norms about physical beauty and desirable features for both women and men in any given culture. Therefore, the docile body increases the forces of the body itself in economic terms of utility and diminishes the same forces in political terms of obedience. We could agree with Foucault when he says that the human body is introduced in a mechanism of power with a social basis, that explores it, breaks it down and rearranges it.

\section{REFERENCES}

[1] Balzac, H. (de) (1843), Illusioni perdute, trad. it. Garzanti, Milano, 1966.

[2] Blacker, C. P., Eugenics: Galton and After, Harvard University Press, Cambridge, 1952.

[3] Bordo, S., Unbearable Weight. Feminism, Western Culture and The Body, University of California Press, Berkeley, 1993.

[4] Ceserani, R., Guida allo studio della letteratura, Roma-Bari, Laterza, 1999.

[5] Chernin, K., The Obsession: Reflections on the Tyranny of Slenderness, Harper \& Row, New York, 1981.

[6] Davis, J. L. (a cura), The Disability Studies Reader, Routledge, New York and London, 1997. 
[7] Siebert R. , Floriani S. (ed.), Andare oltre: La rappresentazione del reale fra letterature e scienze sociali. Ossidiana. Teoria Cultura Vita Quotidiana Vol. 6. Floriani S., Siebert R. (ed.), Chap. 10, "Le storie capitano solo a chi le sa raccontare". Una conversazione con Gabriella Turnaturi", Pellegrini Editore, Cosenza, 2013, pp. 193-218.

[8] Foucault, M., “The Political Investment of the Body", in Fraiser M., Greco, M., The Body: A Reader, Routledge, London, 2005.

[9] Id. (1977), Discipline and Punish. The Birth of The Prison, Engl.tr. by Alan Sheridan, Pantheon, New York, 1978.

[10] Howells C.A., (ed.), The Cambridge Companion to Margaret Atwood, Cambridge University Press, Cambridge, 2006.

[11] Jedlowski, P., Storie comuni. La narrazione nella vita quotidiana, Mondadori, Milano, 2000.
[12] Id., Memoria, esperienza e modernità. Memorie e società del XX secolo, Franco Angeli, Milano, 2002.

[13] Id., Un giorno dopo l'altro. La vita quotidiana fra esperienza e routine, il Mulino, Bologna, 2005.

[14] La Mettrie, J.O., L'homme machine, Elie Luzac, Leyden, 1748.

[15] Orbach, S., Hunger Strike: Anorexia as a metaphor for Our Time, W.W. Norton, New York, 1986.

[16] Parini, E. G., Gli occhiali di Pessoa. Studio sugli eteronimi e la modernità, Lavoro critico: Quodlibet, 2012.

[17] Wendell, S., "Toward a Feminist Theory of Disability" in Davis, J. L. (ed.), The disability Studies Reader, Routledge, New York and London, 1997.

[18] Wood, J. (2008), Come funzionano i romanzi, It.tr., Mndadori, Milano, 2010. 